\title{
ANALYSIS OF WATER QUALITY PARAMETERS IN WELL WATER IN THE VICINITY OF AN INDUSTRIAL ZONE AND ANALYSING SOURCES AMD EFFECTS
}

\author{
U.M.S. Priyanka \& N.J.G.J. Bandara \\ Department of Foresty and Environmental Science, \\ Universily of Sri Yajewardenepura
}

The Ratmalana - Moratuwa area located in the south of Colombo has devcloped as an industrial residential suburb of Colombo in the 1950's. It has been revealed that the environmental problems in the area are very acute due to the activitics of large number of industrics. About 150 industrics are densely packed, within this arca. Most of the industrics are non-agro based industries. They can be catcgorised into several groups such as paint industrics, galvanising industrics, asbcstos industrics, dycing and finishing, pharmaccutical industries and battcry manufacturing industrics. According to an investigation of discharges produced in the area :: was found that major part of the cmlucnt was released via surface drainage to Lunawa and Bolgoda Lakc. The main issuc associated with this industrial pollution is water contamination. Even though many studies have been carricd out on surface water contamination, studics on ground watcr contamination have not been done in detail. The intention of this study was to, analy'se ground watcr samples at various sites of the industrial zone and to relate the results to the present industrial activities of the area. From these studics it was found that the chemical oxygen demand (COD), levels far exceed the acceptable portable water quality standards, indicating high chemical pollution. In addition it was found that Chemical pollutants are prescut in the ground water. Biological Oxygen Demand (BOD) has excecded the tolerant limits for portable water level at several locations. The trace metals that excecd the Icvels are $\mathrm{Zn}, \mathrm{Fc}$, $\mathrm{Cd}, \mathrm{Pb}$, and $\mathrm{Ni}$ which had not been noted in a previous study done by De Silva et al. (1986).

Low $\mathrm{pH}$ values in some of the samples indicate water contamination with acids. Some samples have been contaminated with acids and it was revealcd by low pH of some samiples. Most industrics in the arca dispose their effluents directly in 10 the drainage system without any prior treatments. Ground watcr contamination is thought to be a direct consequence of these incficicnt emuent systems. This study discusses the analytical results of water samples taken from various locations of the industrial area and described the industrial activitics in the area that night have caused this ground water contamination, and discusses possible health cffects due to use of polluted water as a source of portable water in this well water.

Proceedings of the Eighth Annual Forestry and Environment Symposium 2002 of the Department of Forestry and Environmental Science. University of Sri Jayewardenepura, Sri Lanka 